\title{
Genetic variability organisation and gene flow in natural populations of Medicago polymorpha L. prospected in Tunisia
}

\author{
Amel Salhi Hannachi ${ }^{a *}$, Mohamed Boussaid ${ }^{b}$, \\ Mohamed Marrakchi ${ }^{a}$ \\ ${ }^{\text {a }}$ Laboratoire de génétique et de biologie moléculaire, faculté des sciences de Tunis, \\ campus universitaire 1060, Tunis, Tunisia \\ ${ }^{\mathrm{b}}$ Institut national des sciences appliquées et de technologie, Tunis, Tunisia
}

\begin{abstract}
Sixteen accessions of Tunisian germplasm of Medicago polymorpha L. were characterised using enzymatic markers to identify useful phytogenetic resources for their integration in programmes of safeguard and conservation. Protein extracts from populations of this species were analysed by electrophoresis to estimate isoenzyme variation. Two enzymatic systems providing six alleles were chosen from six systems tested. From statistical treatments, it appears that a considerable variation was found between accessions, indicating an interesting genetic potential for selection. Such a result ( $50 \%$ of the total variation due to population differentiation) is in accordance with the strictly autogamous system of reproduction in this taxon. Isozyme data suggest that the level of gene flow between populations of $M$. polymorpha is very low. Additionally, genetic drift may be responsible for strong among-population differentiation. It seems that the genotypic structure of natural populations, as seen from isoenzymatic markers, is not affected by the geographic parameters (distance and altitude). Thus, these markers are of practical interest in the background selection and improvement programmes. (C) Inra/Elsevier, Paris
\end{abstract}

Medicago / genetic variability / isoenzyme / gene flow / germplasm conservation

Résumé - Organisation de la variabilité génétique dans les populations naturelles de Medicago polymorpha $\mathbf{L}$. Pour identifier les ressources phytogénétiques utiles et leur intégration dans des programmes de sauvegarde et de conservation, seize accessions de germoplasm Tunisien de Medicago polymorpha L., sont caractérisées pour leur diversité enzymatique. Les extraits protéiques des populations de cette espèce sont analysés par électrophorèse pour estimer la variation isoenzymatique. Deux systèmes enzymatiques révélant six allèles ont été retenus, parmi les six

\footnotetext{
* Correspondence and reprints
} 
systèmes testés par électrophorèse sur gel d'amidon, pour leur profil électrophorétique polymorphe. Les analyses statistiques ont montré une importante variabilité entre les populations étudiées indiquant un potentiel génétique intéressant pour la sélection. L'hétérogénéité interpopulation est élevée, un tel résultat est en accord avec le système de reproduction strictement autogame de ce taxon. Les données isoenzymatiques suggèrent que le flux génique entre les populations de cette espèce est faible. La dérive génétique est sans doute responsable de la différenciation entre les populations. Par ailleurs, aucun paramètre éco-géographique (distance et altitude) ne semble influencer leur structuration génotypique. Les marqueurs isoenzymatiques ainsi révélés sont très utiles dans des schémas de sélection pour une meilleure efficacité d'amélioration. (C) Inra/Elsevier, Paris

Medicago / variabilité génétique / isoenzyme / flux génique / germoplasm / conservation

\section{INTRODUCTION}

In Tunisia, in the last 10 years, the preservation of plant genetic resources has been of prime concern for wild forage and pastoral legumes because they have been subject to severe genetic erosion. Indeed, the local genetic resources have been damaged by the reduction of range land and overgrazing; pastoral spaces are relegated to the dry areas of the country dominated by irregular rainfall. The results of the erosion factors have been the degradation and rarefaction of the native flora, and the disruption of equilibrium between ever-increasing livestock requirements and limited resources. Species of Medicago and especially the annual species can be used to valorise and enhance resources. The annual species of Medicago constitute an extremely diversified phytogenetic patrimony. By their integration into ley-farming, they can play an important role in crop production increase. They are also able to improve pastoral production in semiarid areas. Medicago is recognised as one of the most important genera of pasture plants in the world. The Mediterranean basin is the centre of the origin of Medicago species and includes the world's greatest variability (Heyn, 1963).

Conscious of the value of these plants, we initiated a large research programme in order to introduce them to fallow and marginal pastoral zones. The aim of this work is: 1) to build an inventory of local Medicago species and to acquire great genetic diversity through a collection of accessions of Medicago species and 2) to evaluate genetically the phytogenetic resources using morphological and physiological traits as well as biomolecular tools. Selection and improvement programmes are based on the search for genetic markers. Isoenzymes electrophoresis is a useful tool for this purpose. The genetic resources assessed by molecular techniques must be considered in conservation strategies.

We used enzymatic markers to characterise Medicago polymorpha. This approach has been widely used in elucidating the genetic structure of Medicago species (Brunel, 1979; McCoy et al., 1991; Kiss et al., 1993; Bullita et al., 1994; Fayed-Lameche et al., 1996; Salhi Hannachi et al., 1997).

Medicago polymorpha L. syn. Medicago hispida Gaertn., the annual species, belongs to the section Spirocarpos of the Medicago genus. It is autogamous (selfpollinating) and diploid ( $2 n=2 x=14$ ) (Lesins and Lesins, 1979). The species is widely distributed throughout the Mediterranean region and tolerates a great 
variety of habitats. The ubiquitous and polyvalent nature of $M$. polymorpha should be noted (Prosperi et al., 1996). Their spiny pods are one of the characteristics favouring their invasion ability; such pods hook onto sheep wool and hay (Coks et al., 1980).

According to Heyn (1963), three botanical varieties should be recognised: brevispina, polymorpha and vulgaris. Several cultivars of this species are commercialised in Australia. The most common are 'circle valley', 'serena' and 'santiago'. These Australian selected varieties are not well adapted to the environmental conditions of North Africa and Europe (Olea et al., 1989; Bullita et al., 1994).

Observations of $M$. polymorpha at natural sites show that it is well adapted to neutral and slightly acid soils (Reid et al., 1989). Its geographical distribution would indicate a preference for the upper semi-arid bioclimatic stage (Abdelkefi et al., 1990, 1992, 1996). M. polymorpha is equally adapted to areas in which the altitude ranges from 10 to $900 \mathrm{~m}$ and rainfall from 100 to $800 \mathrm{~mm}$.

In the present study, we investigated the genetic diversity by means of isozyme markers.

\section{MATERIALS AND METHODS}

\subsection{Plant material}

Isoenzymatic variation was analysed in 16 spontaneous populations of $M$. polymorpha, collected from a wide range of climatic and edaphic conditions in 1990 (Abdelkefi et al., 1990, 1992). The distribution map (figure 1) shows that this species covers a range of bioclimatic stages ranging from the humid to the upper arid. Seeds randomly selected from each population were germinated, and the plants were grown under uniform conditions $\left(25^{\circ} \mathrm{C}\right.$ and 12-h day length).

\subsection{Protein extraction}

Electrophoresis procedures have been described by Salanoubat (1983) and Baatout et al. (1990). For every sample, $50 \mathrm{mg}$ of young leaves were ground in $200 \mu \mathrm{L}$ of extraction sodium ascorbate buffer ( $\mathrm{pH} 8.4$ ) comprising $4.15 \mathrm{mg}$ of sodium ascorbate, $8.35 \mathrm{mg}$ of $\mathrm{D}$ sucrose and $35 \mu \mathrm{L}$ of 2-beta-mercaptoethanol at $4{ }^{\circ} \mathrm{C}$. The homogenate was centrifuged at $13000 \mathrm{rpm}$ for $2 \mathrm{~min}$.

\subsection{Electrophoretic procedures}

The six enzymatic systems (table I) were electrophoresed in $13 \%$ horizontal starch gels. Twenty-four wicks of Whatman $3 \mathrm{MM}$ chromatography paper were moistened with the protein extracts and inserted into slits in the gel.

Migration was anodic and conducted under $50 \mathrm{~mA}$ for $6 \mathrm{~h}$ at $4^{\circ} \mathrm{C}$ in the extraction buffer and at constant power $(16 \mathrm{~W})$. Procedures for staining enzyme activity were as in Brunel (1979), Stuber and Goodman (1980), Cardy et al. (1980) and Goodman et al. (1980) (table I). 


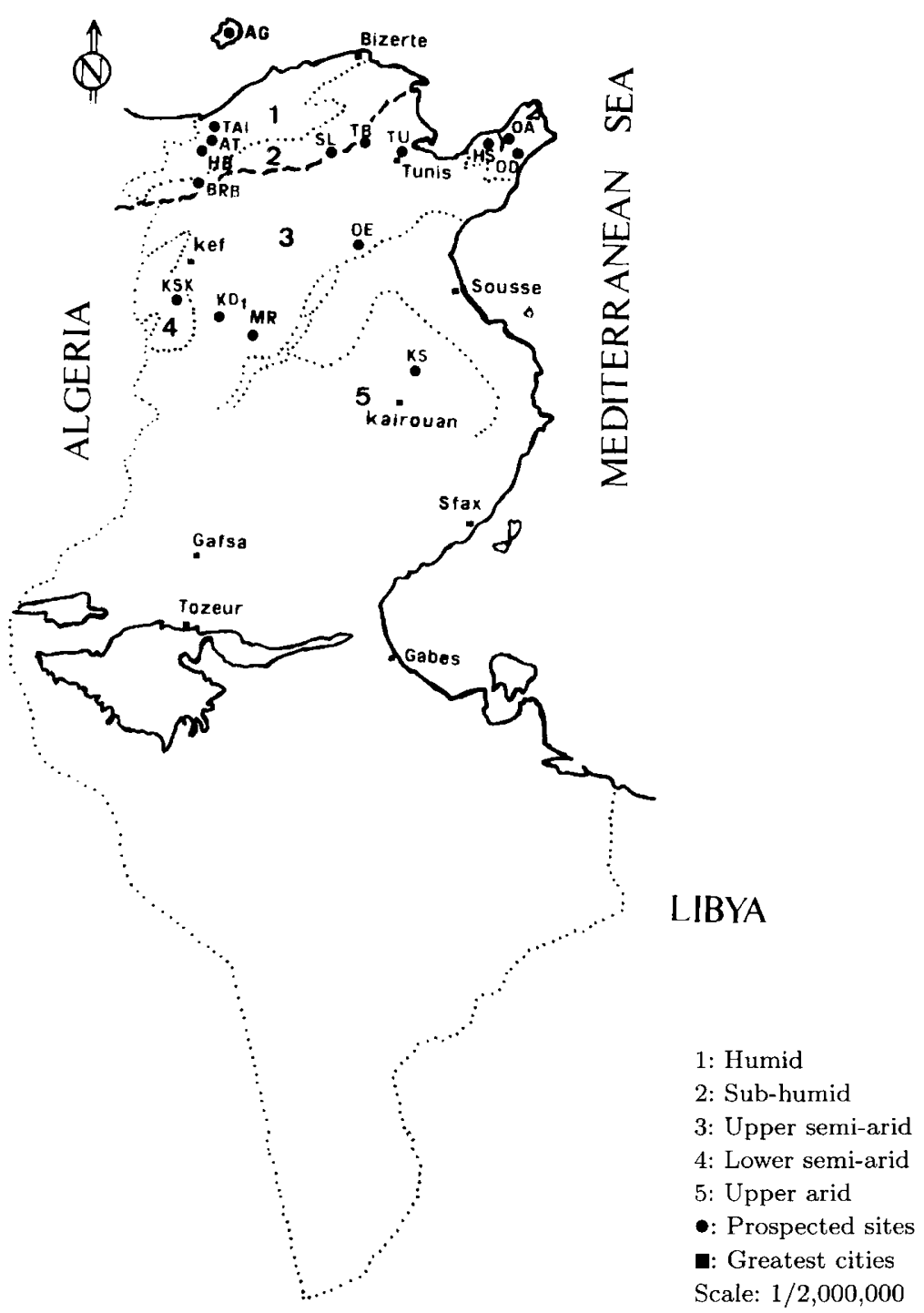

Figure 1. Natural distribution in collection sites of Medicago polymorpha in relation to bioclimatic stages in Tunisia.

\subsection{Data analysis}

The bands of each zymogram were interpreted in terms of loci and alleles. Allelic frequencies were used to describe the distribution of genetic variation within and between populations and to estimate the gene flow among populations. These parameters were estimated from Wright's $F$-statistics (Wright, 1951, 1969; Weir and Cokerham, 1984). 
Table I. Enzyme systems analysed by horizontal starch gel electrophoresis.

\begin{tabular}{|c|c|c|c|c|}
\hline Abbreviation & $\begin{array}{l}\text { European Community } \\
\text { recommended name }\end{array}$ & EC No. & $\begin{array}{l}\text { Subunit } \\
\text { structure }\end{array}$ & $\begin{array}{l}\text { References for } \\
\text { procedures } \\
\text { of staining } \\
\text { enzyme activity }\end{array}$ \\
\hline$G O T$ & $\begin{array}{l}\text { Glutamic-oxaloacetate } \\
\text { transaminase }\end{array}$ & 2. 6.1 .1 & Dimer & $\begin{array}{l}\text { Goodman et al. } \\
(1980)\end{array}$ \\
\hline$I C D$ & Isocitrate dehydrogenase & 1. 1. 1.42 & Dimer & Cardy et al. (1980) \\
\hline$L A P$ & Leucine aminopeptidase & 3. 4.1 .1 & Monomer & Brunel (1979) \\
\hline $6-P G D$ & $\begin{array}{l}\text { 6-Phosphogluconate } \\
\text { dehydrogenase }\end{array}$ & 1. 1. 1.40 & Dimer & $\begin{array}{l}\text { Stuber and } \\
\text { Goodman (1980) }\end{array}$ \\
\hline$P G M$ & Phosphoglucomutase & 2. 7.5 .1 & Monomer & Cardy et al. (1980) \\
\hline$P G I$ & Phosphoglucoisomerase & 5. 3. 1.9 & Dimer & Cardy et al. (1980) \\
\hline
\end{tabular}

Fst measures degree of between-population differentiation; Fis measures within-population variability. A positive value of $F$ is indicates a deficit in heterozygotes in comparison with the Hardy-Weinberg equilibrium expectations.

$F s t$ is widely used to estimate the degree of subdivision between populations. Moreover, the strengths of gene flow and random drift can be assessed from the formula $N m=1 / 4(1 / F s t-1)$, where $N$ is the effective size of a population and $m$ is the rate of migration (Wright, 1969).

Geographical distances between populations have been measured on a map, except when a barrier to migration was present (e.g. Mediterranean Sea). Isolation by distance was estimated according to Slatkin (1993).

The linkage disequilibrium between pairs of loci was estimated for each population using the correlation coefficient (Weir, 1990). Either selection pressures or genetic drift acting on pairs of loci can produce a linkage disequilibrium among two alleles. To distinguish between the two cases, gametic associations of the whole data set $D s t$ were decomposed into four coefficients which show the parts created within populations concerning $D i s$ and $D^{\prime} i s$ indices and between populations with $D s t$ and $D^{\prime}$ st coefficients. According to Ohta (1982), the comparison of Dis and Dst values, on the one hand, and of $D^{\prime} i s$ and $D^{\prime} s t$ values, on the other, allows the two situations to be differentiated.

The $F$-statistics were calculated using GENEPOP (version 1.2) software (Raymond and Rousset, 1995). The overall significance of tests for each locus was estimated by Fisher's combined probability test (Fisher, 1970).

\section{RESULTS}

\subsection{Genetic interpretation}

Allelic frequencies at the three polymorphic loci analysed are reported in table II. A total of six alleles were identified in all loci. Four enzymes appear to be strictly monomorphic: $L A P, P G M, P G I$ and $6-P G D$. 
Table II. Allele frequencies for loci GOT1, GOT2 and ICD1 in populations of M. polymorpha.

\begin{tabular}{llrrllllll}
\hline \multirow{2}{*}{ Populations } & \multicolumn{3}{c}{ GOT1 } & \multicolumn{3}{c}{ GOT2 } & \multicolumn{3}{c}{ ICD1 } \\
& GOTA & GOTB & $N$ & GOTC & GOTD & $N$ & ICDA & ICDB & $N$ \\
\hline OA & 0 & 1.000 & 3 & 0.500 & 0.500 & 24 & 0 & 1.000 & 24 \\
HS & 0 & 1.000 & 13 & 0 & 1.000 & 23 & 0.957 & 0.043 & 23 \\
TAI & 0 & 1.000 & 15 & 0.708 & 0.292 & 24 & 0.708 & 0.292 & 24 \\
OD & 0 & 1.000 & 24 & 0.333 & 0.666 & 24 & 0 & 1.000 & 24 \\
KS & 0.571 & 0.429 & 14 & 0 & 1.000 & 24 & 0.104 & 0.896 & 24 \\
HB & 0 & 1.000 & 16 & 0.875 & 0.125 & 16 & 0 & 1.000 & 16 \\
SL & 0.870 & 0.130 & 23 & 0.522 & 0.478 & 23 & 0 & 1.000 & 23 \\
KD1 & 0.727 & 0.273 & 11 & 0.957 & 0.043 & 23 & 0.065 & 0.935 & 23 \\
MR & $*$ & $*$ & 24 & 0.053 & 0.947 & 19 & 0.053 & 0.947 & 19 \\
TU & 0.023 & 0.977 & 22 & 0.682 & 0.318 & 22 & 0.409 & 0.591 & 22 \\
TB & $*$ & $*$ & 24 & 0.087 & 0.913 & 23 & 0 & 1.000 & 23 \\
AG & 0 & 1.000 & 23 & 0.630 & 0.370 & 23 & 0 & 1.000 & 23 \\
OE & 0 & 1.000 & 7 & 0.458 & 0.542 & 24 & 0 & 1.000 & 24 \\
AT & 0.042 & 0.958 & 24 & 0.417 & 0.583 & 24 & 0.042 & 0.958 & 24 \\
BRB & 0 & 1.000 & 8 & 0.833 & 0.166 & 24 & 0 & 1.000 & 24 \\
KSK & 0 & 1.000 & 7 & 0.667 & 0.333 & 24 & 0.396 & 0.604 & 24 \\
\hline
\end{tabular}

${ }^{*}$ Untested alleles; $N=$ sample size.

\subsubsection{Glutamate oxaloacetate transaminase (GOT)}

Two staining regions are apparent for this enzyme. Each region exhibits three patterns: a triple-banded pattern corresponding to heterozygotes and two single-banded homozygotes for diallelic loci GOT2A, GOT2B and GOT1C, GOT1D. Enzymes GOT1 and GOT2 are thus dimeric. Interlocus interaction is not apparent (figure 2).

\subsubsection{Isocitrate dehydrogenase (ICD)}

Only one gene coding for this enzyme has been detected in $M$. polymorpha. This gene appears to be polymorphic and biallelic (ICD1A, ICD1B). The ICD isozymes (figure 2) produced zymograms with one or three bands, suggesting that those with one band were homozygote phenotypes, and those with three bands heterozygotes.

Only one monomorphic zone of enzyme activity with a single band for $L A P$ (monomeric enzyme) and PGI (dimeric enzyme) was stained. Two monomorphic bands were detected in all populations for $P G M$ (monomeric system) and 6-PGD (dimeric protein) (figure 2).

The rare heterozygote individuals detected by electrophoresis prompted us to use allelic frequency to test the autogamous reproduction system of $M$. polymorpha using the Fis parameter (table III). This test showed that the populations studied were not panmictic. The observed heterozygosity deficiency confirms the autogamous nature of the system of reproduction but with the occurrence of a residual allogamy. The average heterozygosity was 0 to $0.055 \%$ of the sampled polymorphic loci. 


\begin{tabular}{|c|c|c|c|c|c|c|c|c|c|c|c|}
\hline Palterns & I & II & III & IV & $\bar{V}$ & VI & VII & VIII & Bands & Allcles & Zonc \\
\hline \multirow{6}{*}{$\underbrace{(-)}_{(+)}$} & & & & & & - & $\ldots$ & 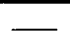 & 6 & GOTIA & \\
\hline & & & & & & & & & 5 & GOTIAB & 2 \\
\hline & 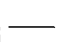 & - & & & - & & & 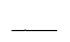 & 4 & GOTIB & \\
\hline & $\ldots$ & & & $\ldots$ & - & & $\ldots$ & 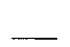 & 3 & GOT2C & \\
\hline & & & & & $\ldots$ & & & & 2 & GOT2CD & 1 \\
\hline & & - & 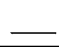 & & - & - & & & 1 & GOT2D & \\
\hline Geno- & $\overline{\mathrm{BB}}$ & $\overline{\mathrm{BB}}$ & $\overline{D D}$ & $\overline{C C}$ & $\overline{\mathrm{BB}}$ & $\overline{\mathbf{A A}}$ & $\overline{\mathbf{A A}}$ & $\overline{\mathrm{AB}}$ & & & \\
\hline types & CC & DD & & & CD & DD & $\mathrm{CC}$ & $\mathrm{CC}$ & & & \\
\hline
\end{tabular}

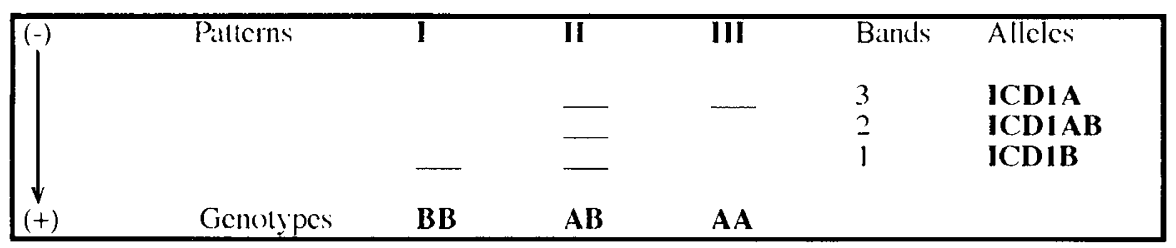

Figure 2. Banding patterns obtained for two polymorphic enzymes (GOT and $I C D)$ in populations of Medicago polymorpha $\mathrm{L}$.

Table III. Departure from Hardy-Weinberg proportions for loci GOT1, GOT2 and ICD1 in populations of $M$. polymorpha using Fis according to Weir and Cokerham (1984) is indicated.

\begin{tabular}{|c|c|c|c|c|c|c|}
\hline \multirow[t]{2}{*}{ Populations } & \multicolumn{2}{|c|}{ GOT1 } & \multicolumn{2}{|c|}{ GOT2 } & \multicolumn{2}{|c|}{$I C D 1$} \\
\hline & Fis & $P$ & Fis & $P$ & Fis & $P$ \\
\hline $\mathrm{OA}$ & $*$ & $*$ & +1 & 0.0000 & * & * \\
\hline HS & * & $*$ & $*$ & $*$ & +1 & 0.0222 \\
\hline TAI & $*$ & $*$ & +0.806 & 0.0000 & +0.806 & 0.0000 \\
\hline OD & $*$ & $*$ & +0.531 & 0.0153 & * & $*$ \\
\hline $\mathrm{KS}$ & +1 & 0.0001 & * & $*$ & +0.785 & 0.0071 \\
\hline HB & $*$ & $*$ & +0.455 & 0.1902 & $*$ & * \\
\hline SL & +1 & 0.0002 & +1 & 0.0000 & $*$ & * \\
\hline KD1 & +1 & 0.0022 & +1 & 0.0222 & +0.656 & 0.0667 \\
\hline MR & $*$ & * & +1 & 0.0270 & +1 & 0.0270 \\
\hline $\mathrm{TU}$ & * & $*$ & +1 & 0.0000 & +1 & 0.0000 \\
\hline $\mathrm{TB}$ & $*$ & $*$ & +1 & 0.0016 & * & * \\
\hline $\mathrm{AG}$ & $*$ & $*$ & +0.911 & 0.0000 & $*$ & * \\
\hline $\mathrm{OE}$ & $*$ & $*$ & +1 & 0.0000 & $*$ & $*$ \\
\hline $\mathrm{AT}$ & +1 & 0.0213 & +1 & 0.0000 & +1 & 0.0213 \\
\hline BRB & $*$ & $*$ & +1 & 0.0000 & $*$ & * \\
\hline KSK & $*$ & * & +1 & 0.0000 & +0.748 & 0.0003 \\
\hline
\end{tabular}

Bold type indicates significance $(P<0.05) ;{ }^{*}$ monomorphic locus; $P$ : the probability of Fisher's exact test on contingency table. 


\subsection{Population differentiation}

The distribution of genetic variation within and among the 16 populations, using $F$-statistics, showed high genetic interpopulational differentiation. The overall differentiation among populations was highly significant $\left(P<10^{-5}\right)$ and corresponded to an Fst value of 0.49 (table $I V$ ), indicating significant genetic heterogeneity between the populations studied.

GOT1, GOT2 and ICD1 loci contributed to the distinction between populations by $F S T$ values of $0.68,0.34$ and 0.56 , respectively (table $V$ ).

Table IV. Fst and probability values $(P)$ from contingency tests in $M$. polymorpha.

\begin{tabular}{lcc}
\hline Locus & Fst & $P$ \\
\hline GOT1 & $0.68483^{*}$ & $<10^{-5}$ \\
GOT2 & $0.34235^{*}$ & $<10^{-5}$ \\
ICD1 & $0.56874^{*}$ & $<10^{-5}$ \\
Mean & $\mathbf{0 . 4 9 8 0 3}^{*}$ & \\
\hline
\end{tabular}

* Highly significant values; bold type indicates the multilocus estimate; $P$ : the probability of Fisher's exact test.

Table V. Summary of Wright's $F$-statistics at all polymorphic loci in $M$. polymorpha.

\begin{tabular}{lcccc}
\hline Locus & Fit & Fst & Fis & $P$ \\
\hline GOT1 & $\mathbf{+ 0 . 9 8 4 8}$ & $\mathbf{+ 0 . 6 8 4 8}$ & $\mathbf{+ 0 . 9 5 1 6}$ & $<10^{-5}$ \\
GOT2 & $\mathbf{+ 0 . 9 4 6 2}$ & $\mathbf{+ 0 . 3 4 2 3}$ & $\mathbf{+ 0 . 9 1 8 2}$ & $<10^{-5}$ \\
ICD1 & $\mathbf{+ 0 . 9 3 5 7}$ & $\mathbf{+ 0 . 5 6 8 7}$ & $\mathbf{+ 0 . 8 5 0 9}$ & $<10^{-5}$ \\
\hline
\end{tabular}

Bold type indicates significant values.

\subsection{Statistical linkage disequilibrium among loci}

Genotypic association among pairs of loci was estimated from correlation coefficients. Estimate of linkage disequilibrium was only significant for the association of GOT2-ICD1, in the (TAI) Tabarka population $\left(P<10^{-5}\right)$ (table $V I$ ). Linkage disequilibrium between loci for pooled populations (table VII) indicated preferential association or linkage between GOT2-ICD1 $(P<0.05)$ and independence between GOT1-GOT2 and GOT1-ICD1 associations (table $V I I)$.

The analysis of the Ohta indices (table VIII) supports the hypothesis that the gametic associations were only due to the action of drift, except for combination of the pair GOT2-ICD1. Ohta indices are presented for both populations in table VIII. Comparison of $D_{I S}$ and $D_{S T}$, on the one hand, and of $D_{I S}^{\prime}$ and $D_{S T}^{\prime}$, on the other, shows that in $M$. polymorpha the disequilibrium between the loci pairs was not systematic and created by genetic drift in each site $\left(D_{I S}<D_{S T}\right.$ and $\left.D_{I S}^{\prime}>D_{S T}^{\prime}\right)$. 
Genetic variability organisation of $M$. polymorpha L. prospected in Tunisia S129

Table VI. Linkage disequilibrium between pairs of loci in populations of M. polymorpha.

\begin{tabular}{lccc}
\hline Populations & Locus \# 1 & Locus \# 2 & $P$ \\
\hline TAI & GOT2 & ICD1 & $<\mathbf{1 0}^{\mathbf{- 5}}$ \\
KS & GOT1 & ICD1 & 1.00000 \\
SL & GOT1 & GOT2 & 1.00000 \\
KD1 & GOT1 & GOT2 & 1.00000 \\
KD1 & GOT1 & ICD1 & 1.00000 \\
KD1 & GOT2 & ICD1 & 0.07693 \\
MR & GOT2 & ICD1 & 1.00000 \\
TU & GOT1 & GOT2 & 1.00000 \\
TU & GOT1 & ICD1 & 0.40810 \\
TU & GOT2 & ICD1 & 0.37593 \\
AT & GOT1 & GOT2 & 0.41567 \\
AT & GOT1 & ICD1 & 1.00000 \\
AT & GOT2 & ICD1 & 0.41243 \\
KSK & GOT2 & ICD1 & 0.58710 \\
\hline
\end{tabular}

Bold type indicates significant estimate.

Table VII. Linkage disequilibrium between loci for pooled populations of M. polymorpha.

\begin{tabular}{lccc}
\hline Pairs of loci & $\chi^{2}$ & $d f$ & $P$ test \\
\hline GOT1-GOT2 & 1.756 & 8 & 0.98761 \\
GOT1-ICD1 & 1.792 & 8 & 0.98673 \\
GOT2-ICD1 & Infinite & $\mathbf{1 2}$ & Highly significant
\end{tabular}

Estimates of $P$-values are indicated; bold type indicates significant estimates.

Table VIII. Ohta's indices computed for the 16 populations of $M$. polymorpha for pairs of loci. $D_{I S}<D_{S T}$ and $D_{I S}^{\prime}>D_{S T}^{\prime}$.

\begin{tabular}{lccccc}
\hline $\begin{array}{l}\text { Pairs of loci } \\
\text { association }\end{array}$ & \multicolumn{2}{c}{ Within populations } & \multicolumn{2}{c}{ Among populations } & Total inbreeding \\
& $D_{I S}$ & $D_{I S}^{\prime}$ & $D_{S T}$ & $D_{S T}^{\prime}$ & $D_{I T}$ \\
\hline GOT1-GOT2 & 0.00231 & 0.93065 & 0.22128 & 0.00092 & 0.93156 \\
GOT1-ICD1 & 0.00158 & 1.40489 & 0.30556 & 0.00888 & 1.41377 \\
GOT2-ICD1 & 0.04454 & 1.04110 & 0.24467 & 0.00057 & 1.04167 \\
\hline
\end{tabular}




\subsection{Population dynamics}

\subsubsection{Gene flow}

Wright (1951) showed that Fst is related to the level of gene flow. The Fst of 0.498 leads to a low value of $N m=0.26(N m<1)$, suggesting a low level of gene flow among populations.

\subsubsection{Isolation by distance}

The distinct ecogeographic origins of studied accessions of $M$. polymorpha were used to identify whether environmental factors are responsible for the allozyme variation. Additionally, gene flow was analysed in relation to geographical distances according to the Slatkin method founded on slope sign of regression between $N m$ and distance of a log. base (Slatkin, 1985, 1993; Chevillon et al., $1995 \mathrm{a}, \mathrm{b})$.

Computing of correlation between $\mathrm{Nm}$ and distance shows that the slope of regression was near zero (figure 3). Another correlation coefficient was calculated between Fst and geographical distance (Pasteur et al., 1995), and again slope was weak $(0.069)$ and regression not significant $(P=0.313>0.05)$ (figure 4). We can conclude that no isolation by distance was detected.

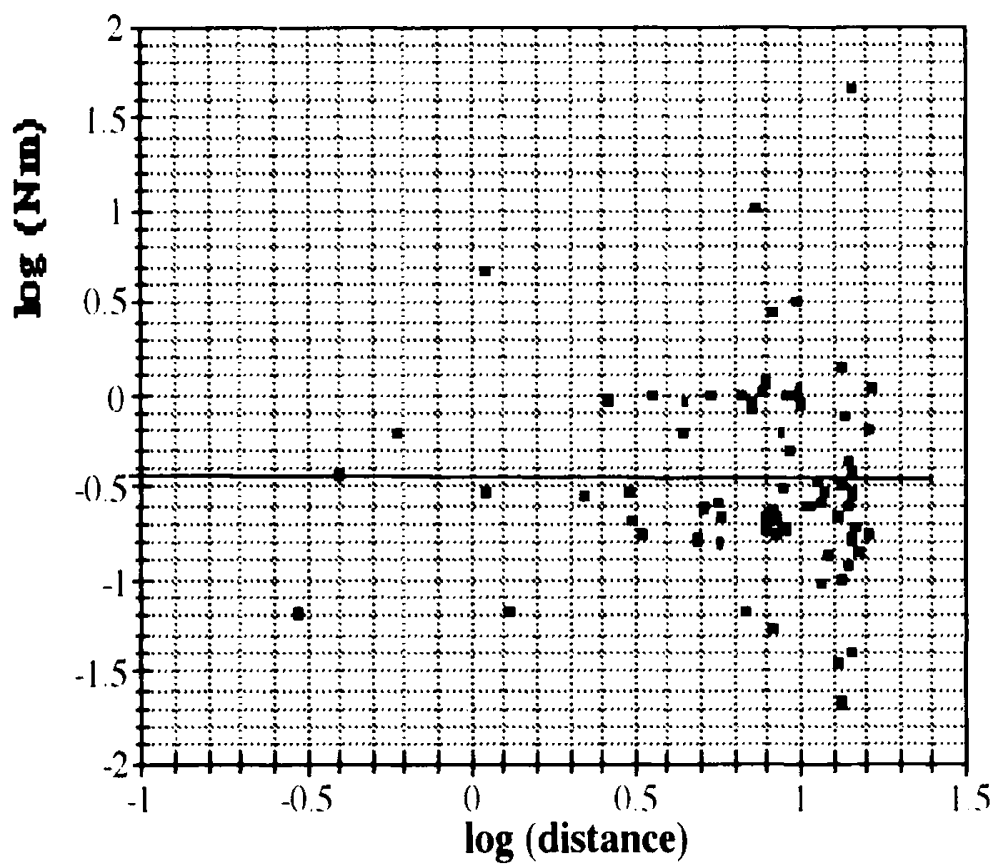

Figure 3. Plot of $N m$ (number of migrants) against geographic distance $(\mathrm{km})$ in populations of Medicago polymorpha. Pairwise estimates of $\mathrm{Nm}$ are calculated using the Fst estimate of Weir and Cockerham (1984). Slope $=-0.017$. 


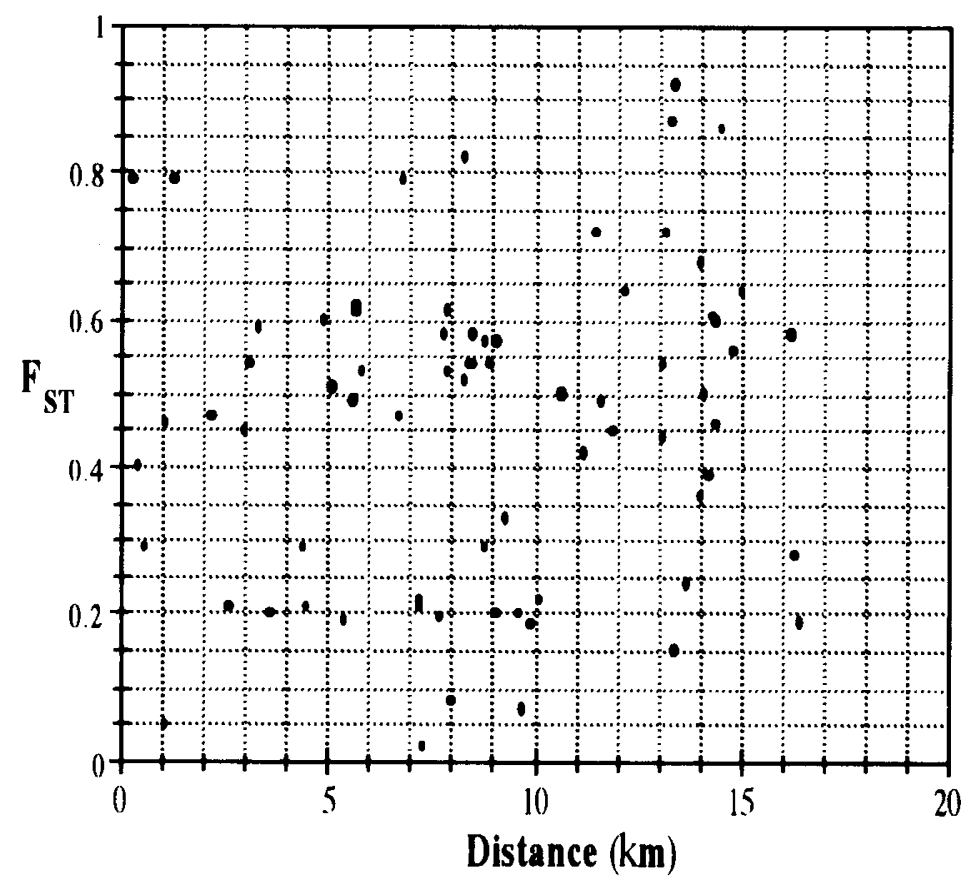

Figure 4. Correlation between Fst and geographic distance for populations of Medicago polymorpha. Slope $=0.069 ; P=0.313>0.05$ not significant.

Structuration of genetic diversity was analysed in relation to the altitude of sites colonised by $M$. polymorpha. Three groups of populations were defined: group I: populations from low altitude (from 10 to $80 \mathrm{~m}$ ); group II: populations colonising stations from 100 to $500 \mathrm{~m}$; and group III: populations native at high altitude (from 650 to $900 \mathrm{~m}$ ).

Table IX shows a differentiation among populations, estimated by $F s t$. The differentiation within each group was stronger than the differentiation between groups ( $F s t$ within groups $>F s t$ among groups). Altitude did not affect the structuration of the genotypes studied.

\section{DISCUSSION AND CONCLUSION}

Previous work showed that in $M$. polymorpha natural accessions a high level of phenotypic diversity exists among populations. The variability range seemed to be continuous over the prospected area. Parameters of precocity, vegetative development and seed production contribute to the distribution of phenotypic diversity (Salhi Hannachi, 1996). Because morphological traits only represent a part of the genetic variability, and because the organisation of this diversity is highly subject to natural selection and environmental factors, knowledge of the evolution and dynamics of populations requires analysis of neutral markers such as isozymes. Neutral markers should help to specify the genetic structure 
Table IX. Comparison of Fst within groups and between altitude groups in M. polymorpha.

\begin{tabular}{|c|c|c|c|c|c|}
\hline & & GOT1 & GOT2 & $I C D 1$ & All \\
\hline \multicolumn{6}{|c|}{ Within groups } \\
\hline \multirow{2}{*}{ Group I } & Fst & 0.6824 & 0.2165 & 0.0689 & 0.4646 \\
\hline & $P$ & $<0.0001$ & 0.0001 & 0.052 & 0.0001 \\
\hline \multirow[t]{2}{*}{ Group II } & Fst & -0.0267 & 0.4400 & 0.7556 & 0.5788 \\
\hline & $P$ & 1 & $<0.0001$ & $<0.0001$ & $<0.0001$ \\
\hline \multirow[t]{3}{*}{ Group III } & Fst & 0.6376 & 0.3734 & 0.4140 & 0.4457 \\
\hline & $P$ & $<0.0001$ & $<0.0001$ & 0.0001 & $<0.0001$ \\
\hline & & Betweer & roups & & \\
\hline \multirow[t]{2}{*}{ Groups I and II } & Fst & 0.3799 & 0.00021 & 0.1881 & 0.1900 \\
\hline & $P$ & $<0.0001$ & 0.25 & $<0.0001$ & $<0.0001$ \\
\hline \multirow[t]{2}{*}{ Groups I and III } & Fst & 0.2109 & 0.1414 & 0.1484 & 0.1675 \\
\hline & $P$ & $<0.0001$ & $<0.0001$ & $<0.0001$ & $<0.0001$ \\
\hline \multirow[t]{2}{*}{ Groups II and III } & Fst & 0.0709 & 0.0773 & -0.0044 & 0.04718 \\
\hline & $P$ & 0.02 & 0.0003 & 0.56 & 0.0004 \\
\hline \multirow[t]{2}{*}{ Allgroups } & Fst & 0.2568 & 0.0794 & 0.0898 & 0.1353 \\
\hline & $P$ & $<0.0001$ & $<0.0001$ & $<0.001$ & $<0.0001$ \\
\hline
\end{tabular}

Bold type indicates significant $F s t$; 'All' refers to multilocus estimate; * Fst not significant.

of populations and the level of gene flow among them. In this study, we investigated genetic variability using several enzymatic systems. Among the six systems tested, two ( GOT and $I C D$ ) were retained. These two systems delivered six alleles and were used to estimate the gene flow between populations, to give information on the organisation of genetic diversity.

The genetic variation occurring within $M$. polymorpha is organised with high levels of differentiation between populations. According to Hamrick and Godt (1990), species that have selfing or mixed mating systems have lower levels of genetic variability than predominantly outcrossed species, and $51 \%$ of their total genetic diversity is apportioned between populations in comparison to $10 \%$ for outcrossed species. Our results on $M$. polymorpha agree with these generalisations $(50 \%$ of the total divergence is attributable to the differentiation among populations). Indeed, the level of variability between altitudinal groups is significantly lower than that between populations within groups. The high levels of autogamy in this species result in a strong pattern of amongpopulation genetic differentiation. Distribution of genetic variability and the extent of gene flow between populations are important for the understanding of genetic evolution. The degree of among-population differentiation is affected by the rate at which genes are carried between populations by the migration of pollen or seeds. The Fst of 0.498 leads to $N m=0.26$, suggesting a low gene flow among populations. This could be due to the high levels of autogamy in $M$. polymorpha. Genetic drift and selection could also result in strong among-population differentiation $(N m<1)$. That selection occurs is suggested by differentiation, albeit rather weak, between altitudinal groups. The high pod dispersal contributes to the observed organisation of variability; the spiny pods favour the invasion of $M$. polymorpha. The pattern observed is typical of species 
with a high dispersal of seeds (Hamrick and Godt, 1990). In M. polymorpha, easy seed dispersal does not prevent isolation of populations. This is confirmed by the noncorrelation between $N m$ and geographic distances separating populations. Genotypic structure is not affected by environmental factors such as distance and altitude. M. polymorpha is interesting because of its ability to adapt to difficult soils and climates. The survey and collection of the genetic resources of this species must be incorporated into conservation strategies. To establish a gene bank we need to know how the genetic variability is organised in the species. In-situ gene banks have been used in Syria and in Iran to select the $M$. polymorpha variety (Cocks et al., 1986; Nazari-Dashlibrown and Francis, 1988). The conservation strategies were fundamental to the development of successful mixtures of $M$. polymorpha for ley-farming systems in Tunisia.

\section{ACKNOWLEDGEMENTS}

The authors would like to thank Dr. Nicole Pasteur from Montpellier II University for helpful discussions and statistical assistance. The authors are also grateful to Dr. Hamouda Hemissi from the Faculty of Sciences of Tunis for correcting the English version of this manuscript.

Support for this research was provided by grants from the 'Ministère de l'Enseignement Supérieur', the 'Secrétariat d'État à la Recherche Scientifique et à la Technologie', the CNRS, France and the French Embassy in Tunisia.

\section{REFERENCES}

Abdelkefi A., Boussaid M., Marrakchi M., Érosion génétique et aridité. Cas de trois légumineuses pastorales, susceptibles d'intervenir dans l'amélioration des parcours en zones arides, Biologia 1 (1990) 91-98.

Abdelkefi A., Boussaid M., Marrakchi M., Prospection et inventaire des espèces spontanées du genre Medicago L. en Tunisie, in : Actes Coll. Inter. Complexes d'espèces, flux de gènes et Ressources génétiques des plantes, Paris, 8-10 janvier 1992 .

Abdelkefi A., Boussaid M., Biborchi A., Haddioui A., Salhi Hannachi A., Marrakchi $\mathrm{M}$., Genetic diversity inventory and valuation of spontaneous species belonging to Medicago L. genus in Tunisia, Cah. Options méditerranéennes 18 (1996) 143-150.

Baatout H., Marrakchi M., Pernes J., Electrophoretic studies of genetic variation in natural populations of allogamous Hedysarum capitatum and autogamous Hedysarum euspinosissimum, Plant Sci. 69 (1990) 49-64.

Brunel D., Recherche du déterminisme génétique de quelques systèmes enzymatiques chez la luzerne (Medicago sativa L.) di- et tétraploïdes, thèse, Université Paris XI, Orsay, France, 1979.

Bullita S., Floris R., Hayward M.D., Loi A., Porqueddu C., Veronesi F., Morphological and biochemical variation in Sardinian populations of Medicago polymorpha L. suitable for Mediterranean conditions, Euphytica 77 (1994) 263-268.

Cardy B.H., Stuber C.W., Goodman M.M., Technique for starch gel electrophoresis of enzymes from maize (Zea mays), Inst. Statistics, Mimeo $\mathrm{N}^{\circ} 1317$, North Carolina State University, Raleigh, NC, 1980.

Chevillon C., Addis G., Raymond M., Marchi A., Population structure in Mediterranean islands and of genetic invasion in Culex pipiens L. (Diptera: Culicidae), Biol. J. Linn. Soc. 55 (1995a) 329-343. 
Chevillon C., Pasteur N., Marquine M., Heyse D., Raymond M., Population structure and dynamics of selected genes in the mosquito Culex pipiens, Evolution 49 (1995b) 997-1007.

Coks P.S., Mathison M.J., Crawford E.J., From wild plants to pasture cultivars: annual medics and subterranean clover in southern Australia, in: Summerfield R.J., Bunting A.H. (Eds.), Advances in Legume Science, Kew Royal Botanic Gardens, UK, 1980, pp. 569-596.

Coks P.S., Sawmy H., Swedan Y., Mawlawi B., Medics on farmer's fields - adaptation of farming to northern Syria. Pasture, Forage and Livestock Program, Ann. Rep. ICARDA, Aleppo, Syria, 1986.

Fayed-Lameche F.Z., Bellatar S., Bouabdallah S., Yahia N., Between and within species variation in annual Medicago species, Cah. Options Méditerranéennes 18 (1996) 161-170.

Fisher R.A., Statistical Methods for Research Workers, 14th ed., Olivier, Boyd, Edinburgh, 1970.

Goodman M.M., Stuber C.W., Lee C.N., Johnson F.M., Genetic control of malate dehydrogenase isozyme in maize, Genetics 94 (1980) 153-158.

Hamrick J.L., Godt N.J., Allozyme diversity in plant species, in: Brown A.H.D., Clegg M.T., Kahler A.L., Weir B.S. (Eds.), Plant Population Genetics, Breeding and Genetic Resources, Sinaner Associates, Sunderland, MA, 43-63; Evol. Biol. 7 (1990) $1-144$.

Heyn C.C., The Annual Species of Medicago. Scripta hierosolymitana, Hebrew University Press, Jerusalem, 1963.

Kiss G.B., Csanadi G., Kalman K., Kalo P., Okresz L., Construction of basic genetic map for alfalfa using RFLP, RAPD, isozyme and morphological markers, Mol. Gen. Genet. 238 (1993) 129-137.

Lesins K.A., Lesins I., Genus Medicago (Leguminosae). A Taxogenetic Study, W. Junk, The Hague, Boston, London, 1979.

McCoy T.J., Echt C.S., Mancino L.C., Segregation of molecular markers supports an allotetraploid structure for Medicago sativa $\times$ Medicago papillosa interspecific hybrid, Genome 34 (1991) 574-578.

Nazari-Dashlibrown P., Francis C.M., Value and potential of medic based ley farming in Iran, technical report, Forestry and Range Organization, Shamarin, Iran, 1988.

Ohta T., Linkage disequilibrium with the island model, Genetics 101 (1982) 139-155.

Olea L., Parades J., Verdasco P., Caracteristicas productivas de los pastos de la dehesa de S. O. DE la peninsula Iberica, SEEP XXIX Elvas, Portugal, 1989, pp. 147-172.

Pasteur N., Marquine M., Rousset F., Failloux A., Chevillon C., Raymond M., The role of passive migration in the dispersal of resistance genes in Culex pipiens quinquefasciatus with French Polynesia, Genet. Res. 66 (1995) 139-146.

Prosperi J.M., Angevain M., Bonnin I., Chaulet E., Genier G., Jenczewski E., Olivieri I., Ronfort J., Genetic diversity, preservation and use of genetic resources of mediterranean legumes: Alfalfa and Medics, Cah. Options Méditerranéennes 18 (1996) 71-90.

Raymond M., Rousset F., GENEPOP, version 1.2, a population genetics software for exact tests and ecumenicism, J. Hered. 86 (1995) 248-249.

Reid R., Konopka J., Rihana J.R., Needs and priorities collection of annual medic germoplasm, in: Christian S., Materon L., Falcinelli M., Cocks P. (Eds.), Introducing of the Ley Farming to the Mediterranean Basin, International Centre for Agricultural Research in the Dry Area, Aleppo, Syria, 1989, pp. 253-270. 
Salanoubat M., Polymorphisme enzymatique et évaluation des ressources génétiques: application à l'étude d'une collection de maïs (Zea mays L.), thèse, Univ. Parissud, Orsay, France, 1983.

Salhi Hannachi A., Analyse de la diversité génétique des populations spontanées de Medicago polymorpha L., thèse, Faculté des Sciences de Tunis, Tunisia, 1996.

Salhi Hannachi A., Boussaid M., Marrakchi M., Diversité génétique de quelques populations spontanées de Medicago polymorpha L.: variabilité morphologique et polymorphisme isoenzymatique, in : Rencontre internationale Gestion des ressources génétiques des plantes en Afrique des savanes, Bamako, 24-28 février 1997, Bureau des ressources génétiques, Paris, 1997.

Slatkin M., Rare alleles as indicators of gene flow, Evolution 39 (1985) 53-65.

Slatkin M., Isolation by distance in equilibrium and non-equilibrium populations, Evolution 47 (1993) 264-279.

Stuber C.W., Goodman M.M., Genetics of 6-PGD in corn Maize, Genet. Cooperation Newsletter 54 (1980) 99.

Weir B.S., Intraspecific differentiation, in: Hillis D.M., Moritz C. (Eds.), Molecular Systematics, Sunderland, MA, Sinaner Associates, 1990, pp. 373-410.

Weir B.S., Cockerham C.C., Estimating F-statistics for the analysis of population structure, Evolution 38 (1984) 1358-1370.

Wright S., The genetical structure of populations, Ann. Eugen. 15 (1951) 323-354.

Wright S., The Theory of Gene Frequencies, vol. 2, University of Chicago Press, Chicago, 1969. 